\title{
Inclusive Education for Children with Special Needs in India: A Review Study
}

\author{
Sultan Singh \\ Assistant Professor, Department of Education Lady Irwin College, University of Delhi
}

\begin{abstract}
The child with special needs having problems like personal, social and many times academics in the school and they feel isolated in their environment and society. Earlier there were only special schools which taken care of these children problems. But now the philosophy has been changed, special, integration and inclusive approaches have come. The inclusive approach gave lot of emphasis on the educational inclusion of the child without any discrimination. The present paper discuss about the various provision for these children in India for education through acts and policies. There are many researches also conducted to change the attitude of the teachers, parents, professionals and community people towards the inclusion. The results of the studies indicated that the regular school teachers' attitude is more positive for children with special needs. They are in support of inclusive education of students with special needs. For the successful inclusion, the teachers suggested that there is a need for in-services training for normal school teachers on management of students with special needs, need for the best school policies, and support from the society, parents of disabled and nondisabled students.

Keywords: District Primary Education Program (DPEP) Integrated Education for Disabled Children (IEDC) National Policy on Education (NPE) Persons with Disabilities Act (PWD Act) Project Integrated Education for the Disabled (PIED)
\end{abstract}

\section{Introduction}

Historical Perspectives of Inclusive Education

More than half-a-century ago in 1948, the Universal Declaration of Human Rights was adopted by the United Nations General Assembly. In 1975, the same body adopted the Declaration on the Rights of Disabled Persons. Many important Conventions, Declarations and Action Plans have been either ratified, acceded to, or accepted by governments and international and national non- governmental organizations. Those which related directly to "Education for All", particularly disabled children, are The Convention on the Rights of the Child, 1989, United Nations Economic and Social Commission for Asia - Pacific (UNESCAP) Report in 1999 on "Education for Children and Youth with Disabilities into the $21^{\text {st }}$ Century". The World Declaration on Education for All and its Framework for Action to meet Basic Learning Needs, 1990, Article 3, Clause 5, states "the learning needs of the disabled demand special attention. Steps need to be taken to provide equal access to education to every category of disabled persons as an integral part of the education system." Nothing could be more clearly stated. The Declaration and Framework were accepted with the year 2000 as the target for completion. But today, after the deadline is over, the scenario remains disheartening.

\section{Indian Initiatives to Implement Inclusive Education}

The Indian Education Commission (1964-66): The Indian Education Commission was the first statutory body to suggest that the education of handicapped children has to be organized not merely on humanitarian grounds, but also on grounds of utility. The Commission observed that although the Indian Constitution had issued specific directives about compulsory education for all, including children with disabilities, very little had been done in this regard. The Commission also emphasized that the education of children with disabilities should be "an inseparable part of the general education system." At the time when the Commission made its recommendations there were les than 250 special schools in India. The Commission set the following targets to be achieved by 1986: education for about 15 percent of the blind, the deaf and orthopedic ally handicapped and 5 percent of the mentally retarded. The commission also specifically emphasized the importance of integrated education in meeting this target as it is cost-effective and useful in developing mutual understanding between children with and without disabilities.

Integrated Education for Disabled Children (IEDC, 1974): In 1974, the Ministry of Social Justice and Employment, Government of India, initiated the IEDC program to promote the integration of students with mild to moderate disabilities into regular schools. Children were to be provided financial support for books, stationary, transport, special equipment and aides. The governments were provided 50 percent financial assistance to implement this program in regular schools. 
National Policy on Education (NPE, 1986-92): In 1986, the Indian Government formulated the National Policy on Education for all government schools and articulated a need to integrate students with disabilities. It emphasized that whenever feasible, the education of children with motor handicapped and other mild disabilities should be provided in regular schools. It also emphasized the need to restructure primary teacher training programs to prepare teachers to deal with the special difficulties of children with disabilities.

Project Integrated Education for the Disabled (PIED, 1987): In 1987, the Ministry of Human Resource development (MHRD) in association with UNICEF and the National Council for Educational Research and Training (NCERT) undertook "Project Integrated Education for the Disabled" (PIED). The aim of the project was to strengthen the implementation of the IEDC scheme.

District Primary Education Program (DPEP, 1994): A centrally sponsored scheme, the District Primary Education Program aims to reduce the overall dropout rates of all students enrolled in primary classes, to raise their achievement levels and to provide primary education for all children, including children with disabilities. This is probably the largest program of the central government in teams of funding.

The Persons with Disabilities Act (PWD Act, 1995): A close examination of the national initiative discussed so far indicates that although the Indian Government had made several attempts to implementation integrated education programs; it lacked a firm commitment to promote integration. This was largely because the Indian Government had considered provision for children with disabilities to be a welfare issue rather than an educational imperative. The PWD Act proposed the provision of improved educational services, medical care vocational training, employment, and social security for all persons with disabilities. The Act stated that whenever possible, students with disabilities should be educated in regular school settings.

\section{What are the existing practices of Inclusive Education in India?}

Both full-fledged inclusive education programs and quasi-inclusive program are being practiced in various forms by different organizations in India. At present, at least 7 implementing strategies of inclusive education are observed in India.

They are listed as follows:

- Resource models where children with disabilities study in general school and stay in hostels meant for non-disabled children.

- Resource models where children with disabilities study in general schools and stay with parents at home.

- Semi-resource models or cooperative models where children with disabilities are taught only by the resource teacher in a separate class in a general school.

- Itinerant model where a resource teacher visits the child in his /her local school and the child stays with parents.

- Multi- category resource model where disabled children of different kinds are educated in a general school by the regular teachers and a particular locality.

- Multi- category itinerant model where one special teacher attend to the needs of disabled children of different categories in a particular locality.

An ideal inclusive education concept aims at facilitating total integration of the child in the community. The upcoming inclusive education programs in India are avoiding separation of children with disabilities from their families for the purpose of education.

\section{Review of Literature:}

The study "A study on opinions of regular primary school teachers towards inclusive education of children with mental retardation" (2), was conducted in Kerala to find out the opinions of regular primary school teachers towards inclusion of children with mental retardation. The samples of the study were 60 regular teachers in which 28 male and 32 female working in the Government and Private schools. A questionnaire was used to measure the opinions of the teachers. Independent t-test and one way ANOVA was done to compare the opinions with respect gender, age, and education, level of mental of students' retardation and Government and Private school teachers. The results of the study indicate that in general majority of primary school teachers were in support of inclusive education of children with mental retardation. No significant difference was found with respect to age/gender/education of teachers on inclusive education of children with mental retardation. The findings of the study also revealed that there is significant difference in the teachers' opinions with respect to level of retardation of students. However, they wanted only children with mild mental retardation in their classroom. Further, there is no significant difference between private and govt. school teachers.

The study "Variables that affect teachers' attitudes towards disability and inclusive education in Mumbai, India" (Kala, 2006), determined that teacher attitude is one of the most important variables in the education of children with disabilities. Attitudes of general educators in the city of Mumbai, India, toward disabilities and inclusion of students with disabilities into regular schools were studied through the usage of two attitude scales. The study investigated whether variable background characteristics such as age, gender, income 
level, education levels, years of teaching experience, acquaintance with a person with a disability, having a family member with a disability, frequency of contact and closeness to a person with disability affect the attitudes of teachers towards people with disabilities and towards inclusion of students with disabilities into regular schools. The analyses revealed that while some of the variables of interest did affect teachers' attitudes towards disabilities, the only variable that affected teachers' attitudes towards inclusion was prior acquaintance with a person with a disability

The study "A study on the attitude of regular teachers', resource teachers, Visually Impaired Children, Sighted Children and School Administrators towards inclusive education" (10), was conducted in Coimbatore to find out the attitude of regular teachers and resource room teachers school administrators and visually impaired children towards inclusive education. In this study the samples were 135 persons among them 40 regular teachers, 40 resource room teachers, 40 visual impaired children and 15 school administrators from rural and urban background. The self - structured interview schedule was used in this study. The mean, SD, SED, T-Test and correlation and co-efficient were used to analyze the data. The results of the study reflect that there is a significant difference between regular teachers, resource teachers, visually impaired sighted children and school administrators towards inclusive education.

The study "Inclusive education for students with disabilities: The challenge for teacher education "(1), focused on the Person with Disabilities ACT, 1995.This poses an unusual demand on regular school teachers to provide responsive education to students with disabilities. However, it is not known whether these teachers are competent to work with disabled students. A survey was conducted in Delhi, to find out their views on a number of issues: competencies they perceive to be important in order to work effectively with students with disabilities, their perceived current level of skill in those competencies and their preferred in service delivery modes. This paper is an outcome of the survey and brings out a number of suggestions to meet the challenge for teacher education in India.

The study "Attitudes towards Integrated Education" (12), investigated the attitudes of visually impaired and sighted pupils in Manchester and New Delhi towards the integration of children with visual impairment into ordinary schools. Attitudes of visually impaired and sighted pupils towards friendship with each other have also been surveyed because friendship reflects integration. Attitudes of visually impaired and sighted, boys and girls, younger and older pupils toward integration and friendship in Manchester and New Delhi have been compared to see if the factors vision, gender, age and location influence the attitudes of pupils. As integrated education for the visually impaired is considered important all over the world, and the expansion of integrated education in India is inevitable on account of its advantages, this book is very useful for students in departments of education in universities, colleges, district institutes of education and training, and national institutes of special education. This book is also helpful to other institutions which conduct training programs for teachers. The book contains valuable information for researchers and professionals of special education.

The study "Priorities of training and attitude of special educators towards people with mental handicap" (3), attempted to examine the priorities of training and attitude of the special educators towards people with mental handicap. Qualified special educators $(\mathrm{N}=26)$ attending a refresher course, were studied through a priority rating and attitude questionnaire. Most special educators indicated early intervention as the most preferred area of training in special education. They agreed that people with mental handicap are burden for the family and do not contribute to the society but in spite of that, parents can love them. They strongly felt that people with mental handicap should be prevented from having sex and children.

The study "Perception of general and special school teachers towards physical disability" (4), attempted to find out the attitudes of general and special teachers towards disability. In this research the sample of special education trainees, special school teachers and general school teachers was taken by the researcher. The results of study show that both men and women teachers, special education trainees and general school teachers have same attitudes towards disability.

Banerjee, Director, Seva-in-Action, Bangalore, presented a paper on Teacher Training Strategies in Integrated Education for Disabled. The success of integrated education depends on how responsive is the general school system to the challenges of children with disabilities. Seva-in-Action with DPEP developed an integrated education program in 1998. Through a study of the existing training program, it was found that teachers had a positive approach towards integrated education, but lacked knowledge and practical skills for teaching special children. There was need for supportive materials for use by resource teachers and general teachers, and decentralization of training at block level and cluster level with more practical input. The objective of the training is to develop Multi category Resource Persons (MRP) who can orient other teachers to promote the development of inclusive education in schools in rural society.

Palliwal presented a paper titled Integrated Education for the Disabled under Sarva Shiksha Abhiyan. The commitment of the Govt. of India to Universalisation of Elementary Education cannot be fully achieved without taking care of special educational needs of the physically and mentally challenged children. Sarva Shiksha Abhiyan (SSA), a project launched by the Department of Elementary Education and Literacy provides 
for IED to fulfil the objective of UEE. However, the provision of Rs.1200 per challenged child per year made under SSA is not sufficient; hence the possibility of convergence of the efforts of other departments / agencies of the Central Govt. is being explored.

\section{Result Analysis}

Hence we can safely conclude that the above mentioned studies tried well to highlight the importance of inclusive education for children with special needs. There are many research studies which explain the role of regular school teacher for children with special needs. The studies also reveal that the coordination between regular school teacher and special educator is important to implement inclusive education for these children. The government has also taken lot of initiatives to strengthen the inclusive in regular schools through different acts and policies. Recently the United Nation Organization (UNO) has passed the United Nation Convention for Rights of Persons with Disabilities (UNCRPD) and India was the first signatory body to implement this law in the country. So that the present paper has focused the review of various researches conducted in the India.

\section{Acknowledgement}

I am great full to all the teachers of the study without whom, the study would not have been possible.

\section{References:}

[1]. Das, A. K., Pillay, A. N. and Diwaker, (2001), Inclusive education for students with disabilities: The challenge for teacher education. $14^{\text {th }}$ National Seminar on Mental Retardation, Deepshikha, Ranchi - India.

[2]. Joseph, J. (2006), “A study on opinions of regular primary school teachers towards inclusive education of children with mental retardation", National Institute for the Mentally Handicapped (NIMH) Secunderabad, Andhra Pradesh

[3]. Jena, S.P.K., (2004), Priorities of training \& attitude of special educators towards people with mental handicap, Disabilities and Impairments. Vol. 14 (2), (87-92).

[4]. Krishnaveni, B. and Pavitra, P (1997), Perceptions of general and special school teachers towards physical disability. Indian Journal of Mental Health \& Disabilities, Vol. (2), No. 1-2

[5]. Mani M.N.G. (1999), UNESCO International Institute for Special Education Proposal submitted to the UNESCO and Government of India. Netsearch : http://www.ICEVI.org.

[6]. Mani, M. N. G., (1994), Project Integrated Education for the Disabled- Evaluation Study, Phase 1, UNICEF, New Delhi. Netsearch : http://www.ICEVI.org.

[7]. Mani, M. N. G., (1994), Project Integrated Education for the Disabled- Evaluation Study, Phase 11, UNICEF, New Delhi. Netsearch : http://www.ICEVI.org.

[8]. Puri, M. and Abraham, G., (2004), Handbook of Inclusive Education for Educators, Administrators, and Planners, Unit - 1 Inclusive Education- An Overview, (17- 25)., Sage Publications India Pvt. Ltd, B-42, Panchsheel Enclave- New Delhi.

[9]. Shanthi, M., (2001), Abstract titled "A Study on the attitude of regular teachers, Resource teachers, Visually Impaired Children, Sighted Children and School Administrators towards inclusive education", Bharathiar University - Coimbtore.

[10]. Soni, R.B.L., (2006), Attitudes towards integrated education, Netsearch: Vedams eBooks (P0 Ltd., New Delhi., (1996 - 2007). vedams@vedamsbook.com 